Egyptian J. Anim. Prod. (2004)4I(1):19-30.

\title{
PRODUCTION OF CALCIUM SALTS OF FATTY ACID FROM SOAP-STOCK ON SEMI INDUSTRIAL SCALE AND ITS USE IN FINISHING RATIONS OF FRIESIAN BULLS
}

\author{
T.M. El-Bedawy ${ }^{1}$, I. A. Gommaa ${ }^{2}$, Sabbah M. Allam ${ }^{1}$ and F.M. Abo- \\ Donia $^{2}$
}

1- Department of Animal Production, Faculty of Agriculture, Cairo University, Giza, Egypt, 2- Animal Production Research Institute, Agriculture Research Center, Ministry of Agriculture, Dokki, Egypt

\section{SUMMARY}

The study was carried out to produce protected fat from industrial waste (soapstock) on semi-industrial scale and to evaluate two levels of supplementation in finishing diets of Friesian bulls. Ten tons of calcium salts of fatty acids (Ca-SFA) was prepared from soap-stock on semi-industrial scale. Protected fat was added in pellet form as a surplus at rate of $4 \%$ and $8 \%$ of total dry matter intake of basal diet (control) of 18 Friesian bulls $(375 \mathrm{Kg}$ ) in three similar groups. Processing had not influenced the proportion of fatty acids of soap-stock and the product is almost insoluble at $\mathrm{pH}$ from 4-6.

Nutrient intake as TDN and DE $(P<0.05)$ increased by about $15 \%$ for $4 \% \mathrm{Ca}$ SFA and $25 \%$ for $8 \%$ Ca-SFA groups. Final body weight, average daily gain and protein efficiency improved, however, energy utilization had not significantly affected by feeding Ca-SF supplemented rations.

Digestibilities of EE,OM,DM and energy increased but digestibilities of crude protein, crude fiber and nitrogen free extract had not been affected by fat supplement. Also, numinal fermentation and nitrogen metabolism were not significantly affected except an increase in protozoa count and a decrease in ruminal pH. Ca-SFA increased the concentrations of plasma lipids and calcium.

It could be concluded that soap-stock as an industrial waste could be efficiently utilized as animal feed to prepare protected fat which could be successfully incorporated up to $8 \%$ of ration DM of fattening bulls.

Keywords: Friesian bulls, calcium sals of fatty acids, growth.

\section{INTRODUCTION}

Under intensive systems of ruminant production and the high genetic potential for meat and milk production, higher amount of cereal grains are required in the diets to increase digestible energy intake. This high need for energy, the negative effects of excess starch feeding and the increased availability of feed-grade fats has led to renewed interest in using fat to increase density of diets for ruminants (Palmquist and

Issued by The Egyptian Society of Animal Production 
Jenkins, 1980). On the other hand, fat addition to ruminant rations depresses fiber digestion in rumen (Palmquist and Jenkins, 1982). Such ruminal fermentation problems could be minimized, or even eliminated by feeding calcium salts of fatty acids (Jenkins, 1994).

Protected fat is widely used at commercial level for meat and milk production in the developed countries, but has a limited use in the developing ones because fat or oil used for preparing such protected fat are mostly consumed by human.

Soap-stock as one of the by-products of oil and soap industry containing not less than $60 \%$ fatty acid was used as a source of fatty acid to prepare protected fat in order to reduce fat feeding cost. environmental pollution and competition of human and animals on fat sources.

The aim of. this study was to produce protected fat from industrial waste (soapstock) on semi-industrial scale and to evaluate two levels of supplementation in finishing diets of Friesian bulls.

\section{MATERIALS AND METHODS}

Ten tons of calcium salts of fatty acids (Ca-SFA) was prepared from soap-stock on semi-industrial scale at Cairo Oil and Soap Co. Soap stock was treated with $14 \%$ calcium chloride $\left(40 \% \mathrm{w}\right.$ : v solution) under steam at $130^{\circ} \mathrm{F}$ in a processing kettle. The product was skimmed and air dried at room temperature to about $80 \% \mathrm{DM}$. The produced Ca-SFA was pelletted in $1 \mathrm{~cm}$ length and $3 \mathrm{~mm}$ diameter. Chemical composition of Soap-stock and its calcium salts is shown in Table 1. Physical and chemical tests including solubility test (Sukhija and Palmquist 1990), fatty acid composition (A.O.C.S., 1973) were carried out. The relative low ether extract values does not represent the true fat content because such materials need to be analyzed as acidified ether extract as shown in Table 5 .

Eighteen Friesian bulls of about $375 \mathrm{Kg}$ body weight were randomly allotted into three similar groups. Animals were adapted for the experimental rations two weeks before data collection. Initial body weight of the experimental animals is shown in Table 8. Animals were weighed every two weeks during 120 day experimental period.

Concentrate mixture and rice straw were fed according to the biweekly body weight and body weight gain in amounts to cover the NRC (1984) recommended allowances. Pellets of the protected fat were added as a surplus to groups 2 and 3 at rate of $4 \%$ and $8 \%$ of total intake from concentrate and roughages. Animals were individually fed twice a day at 08.00 and 16.00 being watering at 10.00 and 17.30 p.m. Chemical composition of feed ingredients and experimental rations are shown in Tables 5 and 6 .

Two sets of digestion trials were carried out at mid and end of the experimental period using three replicates applying the acid insoluble ash (AIA) technique (Van Keulen and Young, 1977). Therefore, each nutrient digestibility represented an average of six values. During the digestion trials, animals were fed at 06.30 and $18.30 \mathrm{hrs}$ and grap samples were collected at 06.00 and $18.00 \mathrm{hr}$. Chemical composition and gross energy of feeds and feces were determined according to A.O.A.C. (1990). Acidified ether extract of Ca-SFA was determined as described by Drackley et al. (1985).

At the end of the last digestibility trials, rumen fluid samples were collected by 
using stomach tube before and 4 hrs post feeding for two consecutive days. Ruminal $\mathrm{pH}$, total VFA's concentrations (Kromann et al., 1967), molar proportions of VFA's (Erwin et al., 1961), nitrogen fractions (A.O.A.C., 1990), microbial protein (Shultz and Schultz, 1970), ammonia-N (Conway, 1978), protozoa count (Abou El-Naga (1967), total fatty acids (A.O.C.S., 1973) and free fatty acids (Itaya and Ui, 1965) were determined.

Blood samples were withdrawn from the left jugular vein of the same three replicates at the end of the last digestion trials, before morning meal. Red and white blood cells were counted in whole blood samples. Plasma total lipids, triglycerides and cholesterol were determined using commercial kits (Biomerieux 69280 Marcy-1, Etoile, France ${ }^{\circledR}$ ). Free fatty acids (Itaya and Ui, 1965) and calcium (A.O.A.C., 1990) were also determined.

Statistical analysis was carried out using MSTATC (1989). Digestibility and performance data were analyzed as one-way analysis of variance according to the following model : $Y=\mu+x_{i}+e_{i j}$

Where:

$\mathrm{Y}=$ observation

$\mu=$ mean

$x_{j}$ the effect of treatment for $1=1-3,1$ control, $2=4 \%$ CaSFA and $3=8 \%$ CaSFA

$\mathrm{e}_{\mathrm{ij}}=$ experimental error

Rumen and blood data were statistically analyzed as two-way analysis of variance according to the following model : $Y=\mu+x_{i}+x_{j}+x_{i j}+e_{i j k}$

Where:

$\mathrm{Y}=$ observation

$\mu=$ mean

$x_{i}$ the effect of treatment for $1=1-3,1$ control. $2=4 \%$ CaSFA and $3=8 \%$ CaSFA

$x_{j}$ the effect of sampling time for $1=1-2 \quad 1$ before feeding and $2=4$ hrs post feeding

$\mathrm{e}_{\mathrm{i} i \mathrm{k}}=$ experimental error

Duncan's Multiple Range Test (Duncan, 1955) was used to separate the means when the main effect was significant.

\section{RESULTS AND DISCUSSION}

In comparison with soap stock, the product contained less organic matter and more ash mainly calcium due to calcium chloride treatment of soap during the processing practices. The low EE in the product (calcium soap) was a result of washing off for un-saponified fatty acids and non saponified materials from soapstock which improved the quality of the product compared to the soap-stock, the original raw material (Table 1).

Minor differences in fatty acid composition were observed due to preparation process as a decrease in the short chain and an increase in long chain fatty acids. Generally, processing had not influenced the proportion of fatty acids of soap-stock as shown in Table 2. 
Table 1. Comparative composition of soap-stock and its calcium salt

\begin{tabular}{lcc}
\hline Item & Soap-stock & $\begin{array}{c}\text { Calcium salt of } \\
\text { soap-stock }\end{array}$ \\
\hline Dry matter, \% & 69.54 & 97.00 \\
DM composition, \% & 93.56 & 88.34 \\
Organic matter & 12.44 & 5.16 \\
Ether extract & 6.44 & 11.66 \\
Ash & 0.68 & 9.45 \\
Calcium & 5.53 & 0.55 \\
Sodium & 8.00 & 8.14 \\
Energy kcal/g & & 84.24 \\
Fatty acid composition, \% & 81.12 & 83.18 \\
Total fatty acids & 78.79 & 1.06 \\
Saponified fatty acids & 2.33 & 4.10 \\
Un-saponified fatty acids & 10.11 & \\
Non saponified materials & & \\
\hline
\end{tabular}

Table 2. Fatty acid composition, \% of soap stock and its calcium salt

\begin{tabular}{lrcc}
\hline Item & & Soap-stock & $\begin{array}{c}\text { Calcium salt of } \\
\text { Soap-stock }\end{array}$ \\
\hline Caproic & C6:0 & 2 & 0 \\
Cabrilic & C8:0 & 21 & 20 \\
Cabric & C10:0 & 27 & 26 \\
Lauric & C12:0 & 1 & 1 \\
Myristic & C14:0 & 2 & 2 \\
Palmitic & C16:0 & 4 & 5 \\
Stearic & C18:0 & 8 & 9 \\
Oleic & C18:1 & 19 & 20 \\
Linoleic & C18:2 & 14 & 15 \\
Linoleinic & C18:3 & 2 & 2 \\
\hline
\end{tabular}

Physical proprieties of the calcium salt of soap stock fatty acids are presented in Table 3. The tests showed that the product was not soluble in either water or alcohol but was soluble in $\mathrm{HCl}$ at $\mathrm{pH}$ values of 2 to 3 . The solubility test proved that the product is almost insoluble at $\mathrm{pH}$ from $4-6$ at different soaking time up to $12 \mathrm{~h}$.. At lower $\mathrm{pH}(2-3)$, about $80 \%$ of the soap was soluble (Table 4). This might indicate that the product could be insoluble in the rumen environment but soluble in abomasum. Sukhija and Palmquist (1990) found that Ca-SFA of palm fatty acids was stable at $\mathrm{pH}$ $=5.5$, dissociation was recorded to be less than $10 \%$ at $\mathrm{pH}=5.5$, less than 5 at $\mathrm{pH}=6$ and about $1 \%$ at $\mathrm{pH}=6.5$.

Chemical composition of the ingredients (Table 5) and composition of the experimental rations (Table 6) showed that the three rations were comparable in nutrient contents except the EE which was higher in the treatment ration, being $8.93 \%$ for the $4 \%$ Ca-SFA and $11.93 \%$ for the $8 \%$ Ca-SFA supplemented ration. 
Table 3. Physical proprieties of the calcium salt of soap stock fatty acids

\begin{tabular}{lc}
\hline Trait & \\
\hline Color & Yellow \\
Form & Pellets \\
Pellet length & $1-1.5 \mathrm{~cm}$ \\
Diameter & $3 \mathrm{~mm}$ \\
& \\
Solubility in water & Insoluble \\
Solubility in $\mathrm{HCl}$ acid $(\mathrm{pH} 2-3)$ & Soluble \\
Solubility in ether & Insoluble \\
\hline
\end{tabular}

Table 4. Effect of time and pH on the solubility (\%) of the calcium salt of soap stock at $25^{\circ} \mathrm{C}$

\begin{tabular}{lccccccc}
\hline \multirow{2}{*}{ PH } & \multicolumn{7}{c}{ Hours } \\
\cline { 2 - 8 } & 0 & 2 & 4 & 6 & 8 & 10 & 12 \\
\hline 2 & 0 & 60 & 70 & 75 & 80 & 82 & 88 \\
3 & 0 & 56 & 60 & 63 & 77 & 78 & 80 \\
4 & 0 & 1 & 3 & 3 & 3 & 4 & 6 \\
6 & 0 & 1 & 2 & 2 & 2 & 3 & 3 \\
\hline
\end{tabular}

Table 5. Chemical composition of the experimental ingredients

\begin{tabular}{lccc}
\hline Item & Concentrate mixture & Rice straw & Ca-SFA \\
\hline Dry matter,\% & 90.20 & 93.00 & 97.00 \\
Dry matter composition, \% & & & \\
Organic matter & 91.10 & 75.10 & 88.34 \\
Crude protein & 15.50 & 3.51 & 0 \\
Crude fiber & 15.47 & 31.60 & 0 \\
Ether extract & 8.30 & 1.19 & 88.34 \\
N-free extract & 51.83 & 38.80 & 0 \\
Ash & 8.90 & 24.90 & 11.66 \\
Energy, kcal/ kg & 4275 & 3580 & 8144 \\
\hline
\end{tabular}

Table 6. Composition of the experimental rations

\begin{tabular}{lccc}
\hline Item & Control & $4 \%$ Ca-SFA & $8 \%$ CaSFA \\
\hline Ingredient, \% & & & \\
Concentrate mixture & 64.03 & 61.80 & 59.84 \\
Rice straw & 35.97 & 34.36 & 32.72 \\
Ca-SFA & - & 3.84 & 7.44 \\
Chemical composition, \% & & & \\
Dry matter & 91.11 & 93.14 & 91.63 \\
Dry matter composition & & & \\
Organic matter & 85.34 & 85.49 & 85.65 \\
Crude protein & 11.18 & 10.78 & 10.43 \\
Crude fiber & 21.28 & 20.42 & 19.58 \\
Ether extract & 5.74 & 8.93 & 11.93 \\
N-free extract & 47.14 & 45.36 & 43.71 \\
Ash & 14.66 & 14.51 & 14.35 \\
\hline
\end{tabular}


Dry matter intake by the treated groups increased by about $4 \%$ and $8 \%$ which are the same ratios of fat addition. However, energy as DE or TDN intakes were higher $(\mathrm{P}<0.05)$ for the fat supplemented groups than the control one by about $15 \%$ for $4 \%$ $\mathrm{Ca}-\mathrm{SFA}$ and $25 \%$ for $8 \% \mathrm{Ca}-\mathrm{SF}$ groups (Table 7 ). This increase in energy intake could indicate the positive effect of fat addition on energetic value of the fat supplemented diets (Table 9). The effect of added fat on energy intake is variable among studies. Added fat sometimes increases digestible energy intake less than expected when added fat is poorly digested or when added fat reduces digestibility of the basal diet due to the inhibition of fiber digestion in the rumen (Jenkins, 1994).

Table 7. Dry matter, energy and protein intakes by the experimental groups

\begin{tabular}{|c|c|c|c|c|}
\hline Item & Control & $4 \% \mathrm{Ca}-\mathrm{SFA}$ & $8 \% \mathrm{Ca}-\mathrm{SFA}$ & SE \\
\hline \multicolumn{5}{|c|}{ Dry matter intake, $\mathrm{Kg} / \mathrm{h} /$ day } \\
\hline Concentrate mixture & 7.37 & 7.41 & 7.48 & \\
\hline Rice straw & 4.14 & 4.12 & 4.09 & \\
\hline $\mathrm{Ca}-\mathrm{SFA}$ & 0.00 & 0.46 & 0.93 & \\
\hline Total & 11.51 & 11.99 & 12.50 & 0.03 \\
\hline DM intake. $\mathrm{Kg} / 100 \mathrm{Kg}$ & $2.71^{\mathrm{c}}$ & $2.80^{\mathrm{b}}$ & $2.89^{: 1}$ & 0.02 \\
\hline DM intake, $\mathrm{g} / \mathrm{Kg} W^{0.75}$ & $123^{\mathrm{c}}$ & $127^{b}$ & $132^{i}$ & 14 \\
\hline Roughage, \% & $35.99^{a}$ & $34.36^{\mathrm{b}}$ & $32.75^{\mathrm{c}}$ & 0.06 \\
\hline \multicolumn{5}{|l|}{ Digestible energy intake } \\
\hline $\mathrm{M} \mathrm{cal} / \mathrm{h} /$ day & $31.69^{c}$ & $37.33^{\mathrm{b}}$ & $41.18^{\mathrm{a}}$ & 0.39 \\
\hline $\mathrm{M} \mathrm{cal} / 100 \mathrm{Kg} \mathrm{BW}$ & $7.47^{\circ}$ & $8.70^{\mathrm{b}}$ & $9.52^{a}$ & 0.09 \\
\hline $\mathrm{M} \mathrm{cal} / \mathrm{Kg} \mathrm{W}^{0.75}$ & $339^{\circ}$ & $396^{\mathrm{b}}$ & $434^{a}$ & 4 \\
\hline \multicolumn{5}{|l|}{ TDN intake } \\
\hline $\mathrm{Kg} / \mathrm{h} /$ day & $7.02^{c}$ & $8.08^{b}$ & $8.94^{: 1}$ & 0.07 \\
\hline $\mathrm{Kg} / 100 \mathrm{Kg} \mathrm{BW}$ & $1.66^{\circ}$ & $1.88^{b}$ & $2.07^{\mathrm{a}}$ & 0.02 \\
\hline $\mathrm{G} / \mathrm{Kg} \mathrm{W}^{0.75}$ & $75.1^{c}$ & $85.7^{b}$ & $94.3^{\mathrm{a}}$ & 0.8 \\
\hline \multicolumn{5}{|l|}{ DCP intake } \\
\hline $\mathrm{G} / \mathrm{h} /$ day & 771 & 778 & 750 & 20 \\
\hline $\mathrm{G} / \mathrm{I} 00 \mathrm{Kg} \mathrm{BW}$ & 182 & 181 & 180 & 10 \\
\hline $\mathrm{G} / \mathrm{Kg} \mathrm{W}^{0.75}$ & 8.25 & 8.25 & 8.23 & 0.22 \\
\hline
\end{tabular}

it.b.c Means in the same row having different superscripts differ $(\mathrm{P}<0.05)$

Feeding fat supplemented rations during 120 day-finishing period increased final body weight, total weight gain and average daily gain (Table 8). The increase was not proportional with the increase in dietary fat level (Ngidi et al, 1990). The development in body weight is illustrated in Figure 1. The difference among the experimental groups was not obvious before 45 day, then the $8 \%$-Ca-SFA group showed heaviest body weight, followed by the 4\%-Ca-SFA group more than control.

Adding fat did not improve feed conversion ratio as energy units required to produce $1 \mathrm{Kg}$ gain. This could be attributed to that the high energy intake from the fat supplemented rations had not been met by comparable increase in body weight. White et al. (1992) found that efficiency of steers was not affected by fat supplement.

Digestible protein conversion to gain was better in the fat supplemented group than the unsupplemented one. It could refer to that dietary fat could compensate and save dietary prutein (Wu et al., 1991). 
Table 8 . Body weight gain and feed conversion ratio of the experimental groups

\begin{tabular}{lcccc}
\hline Item & Control & $4 \%$ Ca-SFA & $8 \%$ Ca-SFA & SE \\
\hline Initial body weight, Kg & 375 & 374 & 374 & 2 \\
Final body weight, Kg & 474 & 485 & 491 & 2 \\
Gain, Kg & 99 & 111 & 117 & 3 \\
Average daily gain, g/h/day & 824 & 927 & 979 & 29 \\
Feed conversion ratio & & & & \\
DM, Kg / Kg gain & 14.07 & 13.00 & 12.80 & 0.44 \\
DE, Mcal / Kg gain & 38.74 & 40.47 & 42.15 & 0.75 \\
TDN, Kg / Kg gain & 8.59 & 8.77 & 9.16 & 0.31 \\
DCP, g/ Kg gain & 945 & 844 & 799 & 41 \\
\hline
\end{tabular}
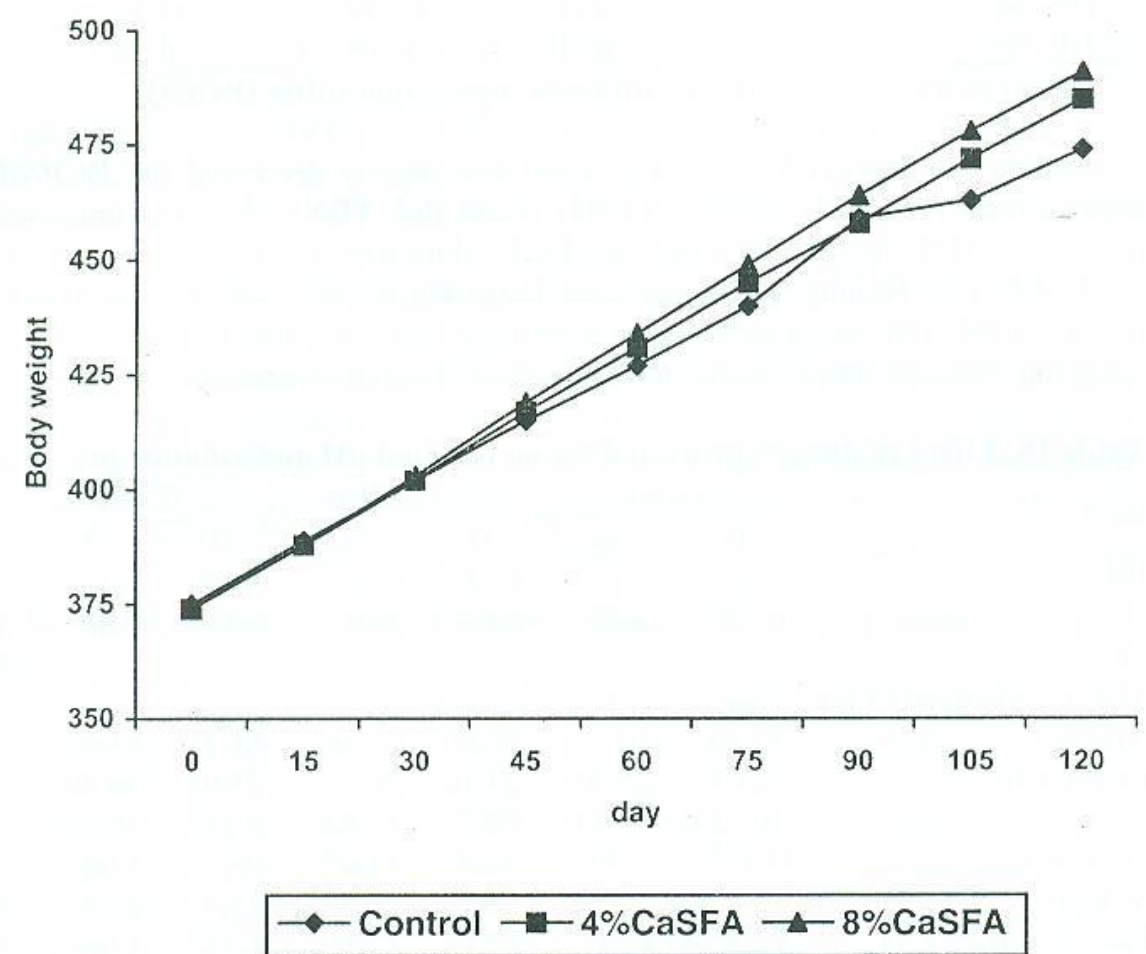

Figure 1. Body weight change during the 120 day experimental period

Fat supplement increased the digestibility of ether extract which resulted in higher digestibility of OM, DM and energy. Digestibilities of crude protein, crude fiber and nitrogen free extract were not affected by fat supplement (Table 9). The high EE digestibility of fat supplemented rations might be due to the high digestibility of added dietary fat (El-Bedawy et al., 1994). Crude fiber was not affected by added fat which could indicate that added fat was protected and did not affect the cellulolytic activity in the rumen. 
Table 9. Effect of dietary protected fat on nutrient digestibilities by the experimental groups

\begin{tabular}{lcccc}
\hline Item & Control & $4 \%$ Ca-SFA & $8 \%$ Ca-SFA & SE \\
\hline Nutrient digestibility, \% & & & & \\
Dry matter & $63.71^{\mathrm{b}}$ & $65.74^{\mathrm{ab}}$ & $67.36^{\mathrm{a}}$ & 0.23 \\
Organic matter & $66.77^{\mathrm{b}}$ & $69.04^{\mathrm{a}}$ & $70.26^{\mathrm{a}}$ & 0.72 \\
Crude protein & 64.01 & 64.02 & 63.90 & 1.52 \\
Crude fiber & 59.27 & 59.42 & 59.28 & 0.77 \\
Ether extract & $70.64^{\mathrm{b}}$ & $83.88^{\mathrm{a}}$ & $83.54^{\mathrm{a}}$ & 1.06 \\
N-free extract & 70.59 & 72.10 & 73.45 & 1.66 \\
Energy & $69.13^{\mathrm{b}}$ & $75.15^{\mathrm{a}}$ & $77.04^{\mathrm{a}}$ & 0.79 \\
Nutritive value & & & & \\
DE Mcal/Kg DM & $2.76^{\mathrm{c}}$ & $3.11^{\mathrm{b}}$ & $3.30^{\mathrm{a}}$ & 0.03 \\
TDN, \% & $61.05^{\mathrm{c}}$ & $67.39^{\mathrm{b}}$ & $71.56^{\mathrm{a}}$ & 0.64 \\
DCP, \% & $6.70^{\mathrm{b}}$ & 6.49 & 6.25 & 0.17 \\
\hline i.t., & Means in the same row having different superscripts differ $(\mathrm{P}<0.05)$ &
\end{tabular}

Adding fat improved the energy value but slightly decreased the DCP of the experimental rations. El-Bedawy (1995) found that TDN value was improved by feeding Ca-SFA supplemented diets but DCP values were not improved.

At $4 \mathrm{hr}$ post feeding, $\mathrm{pH}$ values were lower but the total molar proportion of all rumen volatile fatty acids were higher than those before feeding (Table 10). Effect of sampling time was more obvious than the effect of dietary treatment.

Table 10. Effect of dietary protected fat on ruminal $\mathrm{pH}$ and volatile fatty acids

\begin{tabular}{|c|c|c|c|c|c|c|c|}
\hline \multirow{2}{*}{ Item } & \multicolumn{2}{|c|}{ Control } & \multicolumn{2}{|c|}{$4 \%$ Ca-SFA } & \multicolumn{2}{|c|}{$8 \% \mathrm{Ca}-\mathrm{SFA}$} & \multirow{2}{*}{ SE } \\
\hline & 0 & 4 & 0 & 4 & 0 & 4 & \\
\hline \multirow[t]{2}{*}{ PH } & 6.24 & $5.71^{b}$ & $6.26^{a}$ & $5.68^{b}$ & $6.35^{a}$ & $5.78^{b}$ & 0.14 \\
\hline & $6.85^{b}$ & $8.27^{\mathrm{a}}$ & $6.83^{b}$ & $8.11^{\mathrm{a}}$ & $6.69^{b}$ & $7.80^{\mathrm{ath}}$ & 0.38 \\
\hline \multicolumn{8}{|c|}{ Molar proportion of fatty acids } \\
\hline Acetate & 54.86 & 63.12 & 56.66 & 52.46 & 55.71 & 61.62 & 3.52 \\
\hline Propionate & 22.64 & 25.41 & 23.16 & 26.51 & 25.01 & 28.49 & 3.05 \\
\hline Butyrate & $10.12^{\mathrm{wi}}$ & $13.11^{i 1}$ & $9.65^{\mathrm{cd}}$ & $12.43^{\mathrm{ab}}$ & $8.76^{b}$ & $10.95^{\mathrm{bc}}$ & 0.57 \\
\hline Iso-butyrate & $0.95^{\mathrm{ab}}$ & $1.30^{a}$ & $0.90^{\mathrm{b}}$ & $1.04^{\mathrm{ib}}$ & $0.95^{\text {ith }}$ & $1.08^{\mathrm{abb}}$ & 0.12 \\
\hline Valerate & 1.82 & 2.22 & 1.93 & 2.57 & 2.07 & 2.67 & 0.29 \\
\hline Iso-valerate & $1.25^{b}$ & $1.70^{\mathrm{a}}$ & $1.21^{\mathrm{b}}$ & $1.61^{\mathrm{t}}$ & $1.25^{\mathrm{b}}$ & $1.66^{\mathrm{a}}$ & 0.11 \\
\hline $\mathrm{A} / \mathrm{P}$ ratio & 2.66 & 2.69 & 2.73 & 2.57 & 2.55 & 2.44 & 0.43 \\
\hline
\end{tabular}

Adding dietary fat did not affect nitrogen metabolism in the rumen as shown in Table 11. Ruminal protozoa count was higher for fat supplemented groups and at $4 \mathrm{~h}$ post feeding than that before feeding. However, dietary supplementation of sunflower seed oil ( $6 \%$ of DM) to sheep dramatically reduced protozoa numbers in rumen fluid within 5 days from approximately one million to fewer than $200,000 / \mathrm{ml}$ (Ivan et al., 2001). 
Egyptian J. Anim. Prod. (2004).

Table 11. Effect of dietary protected fat on ruminal nitrogen, fatty acids and protozoa count.

\begin{tabular}{|c|c|c|c|c|c|c|c|}
\hline \multirow{2}{*}{ Item } & \multicolumn{2}{|c|}{ Control } & \multicolumn{2}{|c|}{$4 \% \mathrm{Ca}-\mathrm{SFA}$} & \multicolumn{2}{|c|}{$8 \% \mathrm{Ca}-\mathrm{SFA}$} & \multirow{2}{*}{ SE } \\
\hline & 0 & 4 & 0 & 4 & 0 & 4 & \\
\hline $\begin{array}{l}\text { Total nitrogen,mg/100 } \\
\mathrm{ml}\end{array}$ & 204 & 219 & 203 & 218 & 200 & 218 & 8 \\
\hline $\begin{array}{l}\text { Non protein nitrogen, } \\
\mathrm{mg} / \mathrm{l} 00 \mathrm{ml}\end{array}$ & $72^{b}$ & $83^{\circ}$ & $73^{\mathrm{b}}$ & $83^{a}$ & $73^{b}$ & $82^{a}$ & 3 \\
\hline $\begin{array}{l}\text { Ammonia nitrogen, } \\
\mathrm{mg} / 100 \mathrm{ml}\end{array}$ & $13^{\mathrm{b}}$ & $18^{a}$ & $12^{\mathrm{b}}$ & $18^{a}$ & $12^{b}$ & $17^{\mathrm{a}}$ & 1 \\
\hline $\begin{array}{l}\text { True protein nitrogen, } \\
\mathrm{mg} / \mathrm{l} 00 \mathrm{ml}\end{array}$ & 132 & 136 & 131 & 136 & 128 & 136 & 7 \\
\hline $\begin{array}{l}\text { Microbial protein } \\
\text { nitrogen, } \mathrm{mg} / 100 \mathrm{ml}\end{array}$ & 82 & 84 & 87 & 94 & 84 & 95 & 5 \\
\hline $\begin{array}{l}\text { Protozoa count } x \\
10^{3} / \mathrm{ml}\end{array}$ & $4.12^{\mathrm{c}}$ & $4.74^{b}$ & $4.80^{b}$ & $5.76^{\mathrm{a}}$ & $4.96^{\mathrm{b}}$ & $5.89^{\mathrm{a}}$ & 0.21 \\
\hline $\begin{array}{l}\text { Total fatty acids } \\
\text { mg/gDM }\end{array}$ & $14.00^{c}$ & $17.80^{\mathrm{bex}}$ & $20.98^{\mathrm{bc}}$ & $32.05^{b}$ & $31.40^{\mathrm{b}}$ & $52.40^{a}$ & 5.40 \\
\hline $\begin{array}{l}\text { Free fatly acids, } \\
\mathrm{m} \mathrm{mol} / \mathrm{l}\end{array}$ & $4.00^{\mathrm{ab}}$ & $2.97^{b}$ & $4.51^{2}$ & $4.06^{\mathrm{ab}}$ & $5.94^{\mathrm{a}}$ & $4.94^{a}$ & 0.33 \\
\hline
\end{tabular}

Red blood cell count increased by feeding fat while white blood cell count showed no change. Feeding protected fat increased the plasma concentrations of lipids and calcium (Table 12). Palmquist and Conrad (1978) attributed the high blood plasma lipids of fat supplemented cows to the greater quantity of fatty acids absorbed from fat supplemented diets than the control ones.

Table 12. Effect of dietary protected fat on blood cell counts, plasma lipids and calcium

\begin{tabular}{lcccc}
\hline Item & Control & $4 \%$ Ca-SFA & $8 \%$ Ca-SFA & SE \\
\hline Red blood cells $\times 10^{6} / \mathrm{ml}$ & 5.66 & 6.00 & 6.03 & 0.04 \\
White blood cells $\times 10^{3} / \mathrm{ml}$ & 6.33 & 6.30 & 6.30 & 0.20 \\
Plasma total lipids, $\mathrm{mg} / 100 \mathrm{ml}$ & $509^{\mathrm{b}}$ & $581^{\mathrm{a}}$ & $596^{\mathrm{a}}$ & 14 \\
Plasma triglycerides, $\mathrm{mg} / 100 \mathrm{ml}$ & $65^{\mathrm{b}}$ & $120^{\mathrm{a}}$ & $134^{\mathrm{a}}$ & 8 \\
Plasma cholesterol, $\mathrm{mg} / 100 \mathrm{ml}$ & $196^{\mathrm{b}}$ & $289^{\mathrm{a}}$ & $300^{\mathrm{a}}$ & 10 \\
Plasma free FA, $\mu \mathrm{M} / 100 \mathrm{ml}$ & $19.31^{\mathrm{c}}$ & $32.02^{\mathrm{b}}$ & $38.83^{\mathrm{a}}$ & 1.38 \\
Plasma calcium, $\mathrm{mg} / 100 \mathrm{ml}$ & $9.23^{\mathrm{c}}$ & $10.90^{\mathrm{b}}$ & $11.62^{\mathrm{a}}$ & 0.24 \\
\hline
\end{tabular}

It could be concluded that soap stock as an industrial waste could be efficiently utilized as animal feed to prepare protected fat which could be successfully incorporated in rations of fattening bull up to $8 \%$ of dry matter. 


\section{REFERENCES}

A.O.A.C., 1990. Association of Official Analytical Chemists, International, 1990. Official Methods of Analysis. Vol. I. 15 $5^{\text {th }}$ ed. AOAC, Arlington, VA.

A.O.C.S., 1973. Official and tentative methods of the American oil Chemists Society. Sampling and analysis of soap products. Fatty alkyl sulfates alkyl benzene sulfonates. Section D .

Abou El-Naga, M. A, 1967. Some metabolic studies on rumen microorganisms. M.Sc. Thesis, Faculty of Agriculture, Alexandria University, Egypt.

Conway, E. J., 1978. Microdiffusion analysis and volumetric error. $4^{\text {th }}$ Ed. The McMillan Co., N.Y.

Drackley, J.K., A.K. Clark and T. Sahlu, 1985. Ration digestibilities and ruminal characteristics in steers fed sunflower seed with addition of calcium. J. Anim. Sci., 68:356.

Duncan, D.B., 1955. Multiple Range and Multiple F test. J. Biometerics, 11:1.

El-Bedawy, T. M., 1995. Preparation of sunflower oil calcium soap as a protected fat and its use in ruminant nutrition. J. Agric. Sci. Mansoura Univ., 20:231.

El-Bedawy, T.M.; A.M. Abd El-Gawad; M.A. Gabra and F.A. Scander, 1994. Full fat sunflower seeds oil as fat supplement for dairy cows. Egypt. J. Anim. Prod., 31 (suppl.): 147.

Erwin, E.S.; G.T. Marco and E.M. Emery, 1961. Volatile fatty acid analysis of blood and rumen fluid by gas chromatography. J. Dairy Sci., 44: 1768.

Itaya, K. and M. Ui, 1965. Calorimetric determinations of free fatty acid in biological fluids. J. Lipid Res., 6: 16.

Ivan, M.; P.S. Mir; K. M. Koenig; L. M. Rode; L. Neill; T. Entz and Z. Mir, 2001. Effects of dietary sunflower seed oil on rumen protozoa population and tissue concentration of conjugated linoleic acid in sheep. Small Rum. Res., 41:215.

Jenkins, T.C., 1994. Regulation of lipid metabolism in the rumen. J. Nutr., 124: 1372.

Kromann, R.P., J.E. Meyer and W.J. Stielau, 1967. Steam distillation of volatile fatty acids in rumen digesta. J. Dairy Sci, 50: 73.

MSTATC, 1989. Statistical package. Department of Crop and Soil Science. E. Lansing, Michigan 48824. USA.

Ngidi, M.E.; S.C. Loerch; F.L. Fluharty and D.L. Palmquist, 1990. Effects of calcium soap of long-chain fatty acids on feedlot performance, carcass characteristics and ruminal metabolism of steers. J. Anim. Sci, 68: 2555 .

N.R.C., 1984. Nutrient Requirements of Beef Cattle (6 ${ }^{\text {th }}$ Ed). National Academy Press, Washington, D.C.

Palmquist, D.L. and H.R. Conrad, 1978. High fat rations for dairy cows. Effects on feed intake, milk production and plasma metabolites. J. Dairy Sci., $61: 890$.

Palmquist, D.L. and T.C. Jenkins, 1980. Fat in lactation rations. Review. J. Dairy Sci, 63: 1 .

Palmquist, D.L. and T.C. Jenkins, 1982. Calcium soap as a fat supplement in dairy cattle feeding. Proceedings, XII the World Congress on Disease of Cattle, Amsterdam, pp. 477-481

Shultz, T.A. and E. Schultz, 1970. Estimation of rumen microbial nitrogen by three analytical methods. J. Dairy Sci., 53:781.

Sukhija, P.S and D.L. Palmquist, 1990. Dissociation of calcium soaps of long-chain fatty acids in rumen fluid. J. Dairy Sci., $73 ; 1784$. 
Van Keulen, J. V. and B. A. Young, 1977. Evaluation of acid-insoluble ash as a natural marker in ruminant digestibility studies .J. Anim. Sci., 44: 282.

White, T.W.; L.D. Bunting; L.S. Sticher; F.G Hembry and A.M. Saxton, 1992. Influence in fish meal supplemental fat on performance of finishing steers exposed to moderate or high ambient temperatures. J. Anim. Sci, 70; 3286.

Wu, Z., O.A. Ohahajuruka and D.L. Palmquist, 1991. Ruminal synthesis, biohydrogenation and digestibility of fatty acids by dairy cows. J. Dairy Sci., 74: 3025 . 


\section{إنتاج الدهن المحمى محليا من مخلفات تكرير الزيوت ( الصوب ستوك) على النطاق شبه الصناعى واستخدامه فى علانق التهيئة لعجول التسمين الفريزيان \\ طه محمد البباوى'، أسماعيل جمعة'، صباح محمود علام' و فوزى محمود أبو دنيا'} ا- قسم الإتتاج الحيوانى - كلية الززراعة - جامعة القاهرة - الجيزة - هصر، ب - معهز بحوث الإتتاج

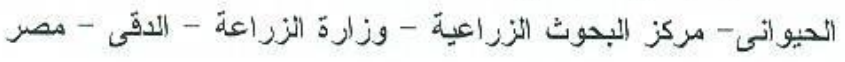

أجريت هذه ألدر أسة بودف إنتاج دهن محمى من مخلفات تكزير الزيوت ( الصوب سنّوك) على نطاق

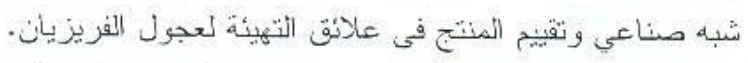

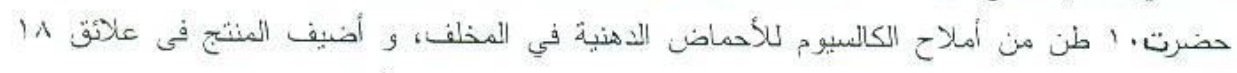

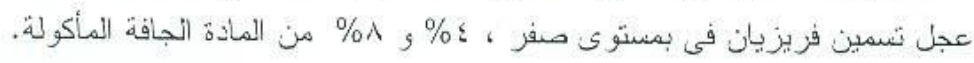

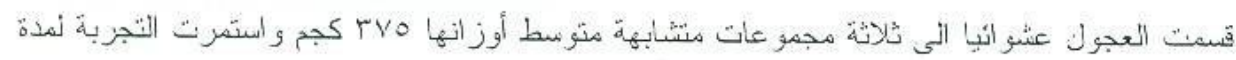

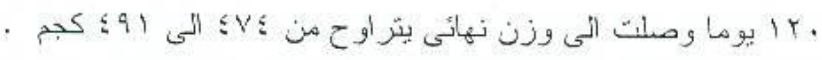

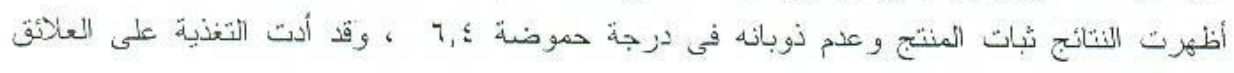

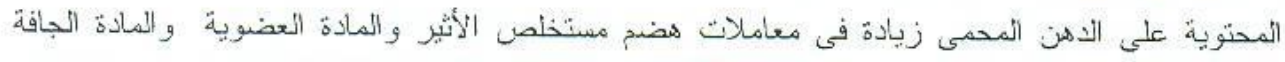

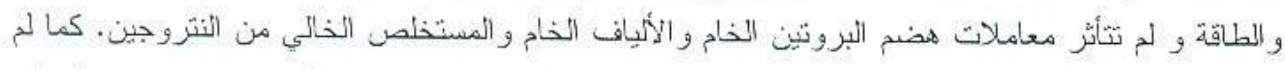

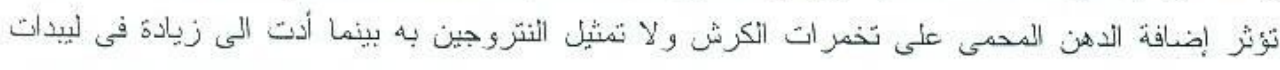

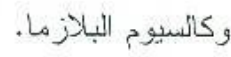

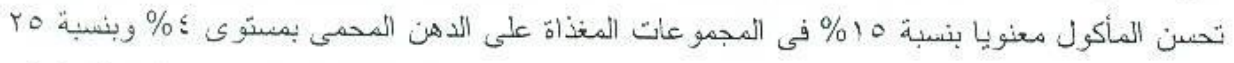

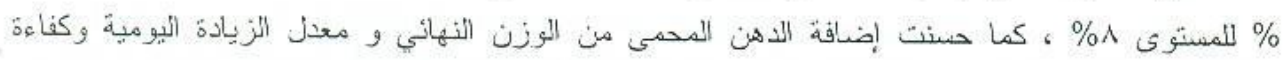

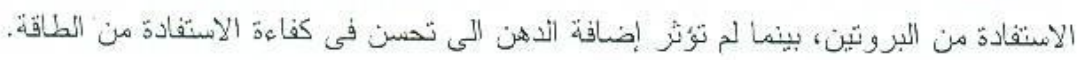

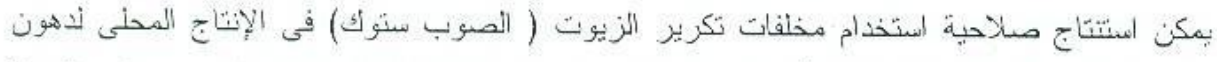

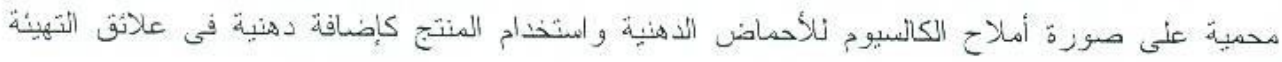

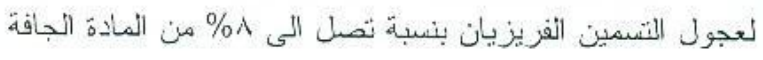

